\title{
Masculine Performance in Hong Kong Crime Films from Post-Bruce to the 2000s
}

ISSN: 2311-8636 (Print)

ISSN: 2312-2021 (Online)

DOI prefix: 10.18034/ajhal

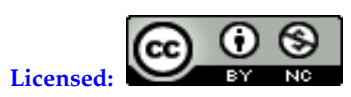

Source of Support: Nil

No Conflict of Interest: Declared

*Email for correspondence:

tsang.fan_yu@kcl.ac.uk

masculinity, similar to 'tragicity' in nature, can be represented through imitating actions and hence be perceived. Based on Aristotle's understanding, we can regard actions as 'iterable' media (like Derrida's understanding of written texts) which engender performances according to the genealogy of quantitative mimesis.

Integrating theoretical discussions with a chronological approach, my full paper will go through following points in order to summarise the changes in Hong Kong crime films from the post-Bruce Lee era to the 2000s: (1) Hong Kong crime film inherited the martial side of masculinity from action films and became a popular genre since A Better Tomorrow was well received in the mid-1980s. (2) Many directors diversified the interpretation of crime in the late 1980s and the 1990s, but remained a focus on the strength, nimbleness and boldness of men. (3) After the decline of Hong Kong film industry for several years, Infernal Affairs's success renewed the representation of manhood. (4) From the 2000s to now, male characters in crime films are preferably intelligent and wisely-romantic, like the fragile scholar in ancient China. (5) While globalisation seems to be eliminating the Chineseness of Chinese masculinity, I argue that geographical specificity and different speed of cultural development lead to the impossibility of synchronic masculine similarity. (6) Through a brief discussion concerning Hollywood's adaptation of Hong Kong films, I argue that local masculinity is not transformable.

Key Words: Hong Kong cinema, crime films, masculinity, Chinese culture, from the 1980s to the $2000 \mathrm{~s}$

\section{Presentation}

Lacan's classification of three realms - the Real, the Imaginary and the Symbolic generates a meta-structural understanding about viewing concepts, fixed by their own definition and terminological boundary, as outcomes of symbolized imagination. In this 
sense, masculinity is fluid, variable, and is unavoidably bounded by conceptualization. Its imaginative nature is not merely about how an individual subjectively perceives this term, but also, more essentially, about how external environment dynamically evokes one's psychological integration of ideas which unconsciously determines what masculinity is. The process of integration is certainly not straightforward. It hierarchizes masculinity in contrast to femininity, rejects unrelated concepts to maximize the cognitive purity of masculinity and allocates masculinity to various social and cultural symbols. Metaphysically speaking, masculinity has no substance. It relies on a series of signification built collectively upon physical characteristics and social inertia concerning male human beings. To theorize masculinity, one necessarily needs to not only understand the innate and developmental features of men, comparing and contrasting them with those of woman, but also figure out how culture metonymically massproduces sense and discourses of masculinity.

Beginning with a denial of "the common superficial appreciation of yin-yang theory", in which "femininity and masculinity are placed in a dichotomous relationship whereby yin is female and yang is male" (p.9), Kam Louie (2002) applies the endless, dynamic interaction between yin and yang to dissolve absolute characterization of masculinity. In the interrogation of the elements of wen (cultural attainment) and wu (martial valour) rendered in historical or artistic male images, he reveals the arbitrary signification of masculinity underneath cultural phenomena. In his view, masculinity not only includes "physical strength and military prowess", but also, especially in the Chinese context, includes "refined qualities that were associated with literary and artistic pursuits of the classical scholars" (p.14). His dualistic illustration of masculinity and further discussion of relevant artistic representations reveals how popular culture inherits traditional imagination of manliness. With no doubt, popular culture is temporary, selective and hierarchical in nature. Creativity is usually more determinative than tradition. While applying Kam Louie's genealogical discussion of masculinity to analyse popular artworks, one should notice that artists usually reinterpret and re-transfigure masculinity with addition, reduction or distortion of its significance, rather than blankly inherit it from traditional trajectory. In the following, I will discuss the development of Hong Kong crime film which transforms masculine performance in Hong Kong from being violent during the 1980s and the 1990s (like those represented in Long Arm of The Law, A Better Tomorrow, the series of Young and Dangerous), to being intelligent (like Infernal Affairs, Overheard and Cold War) since the early 2000s. To go beyond chronological understanding, this paper will end up with a discussion about the locality of masculinity, exemplified by a comparison between American and Hong Kong cases.

As written in Geoff Mayer's Historical Dictionary of Crime Films (2012), "Prior to the mid1980s, the Hong Kong film industry was better known for its kung fu films. [...] The crime genre came to life in Hong Kong with Yingxion $[g]$ bense (A Better Tomorrow, 1986)." (P.217). As an evolutional product, crime film became popular since the mid1980s through absorbing kung fu elements. In terms of action films in general, Lo KwaiCheung (2010) succinctly concludes, "1980s Hong Kong action movies were cheesy and technically backward. The texture of the characters was never complex, and the plot, generally boring and defying common sense, was only a vehicle for the endless action." (P.120).Compared to Bruce Lee's action films which combine innovative actions with philosophy of martial arts, nationalism of diasporas, war-time patriotism, and a sense of self-actualization, the following imitators, especially those during the mid-1970s to the mid-1980s, failed to add value to filmic actions. 
After returning to Hong Kong from the United States, Bruce Lee acted as the protagonist in five feature-length films: The Big Boss (1971), Fist of Fury (1972), Way of the Dragon (1972), Enter the Dragon (1973) and The Game of Death (1973). His muscular and sharp fighting scenes brought great commercial success in Hong Kong and hence refreshed Hong Kong film industry. His challenges to Japanese and Italian fighters in Fist of Fury and Way of the Dragon express Chinese nationalism through wartime and diaspora contexts respectively. The dialogues about how to use a human body in fighting, supporting repetitive fighting scenes throughout all his films, grant his actions artistic depth and spiritual significance.

They were but blank repetition of, what Kam Louie identifies as, $w u$ masculine performance - martial action in contrast to cultural action (wen performance). With reference to Aristotle's discussion of mimesis, Chinese masculinity, similar to "tragicity" in nature, is representable in a way that through fabricated actions it can let audience perceive a sense of masculinity. Hence, actions can be regarded as "iterable" media (like Derrida's understanding of written text) which engender filmic performance according to the genealogy of quantitative mimesis. As mentioned before, the creative process involves addition, reduction or distortion of past concepts. In the case of post-Bruce action films, in order to formulate action film for mass production in response to increasing market demand, both local and overseas, Hong Kong directors and scriptwriters tended to simplify plots and storylines and let male characters fight for the sake of fighting. Their overemphasis on violent fighting, fist-oriented righteousness and exposure of muscular bodies shaped and delimited masculine representation in that era. Two decades after the death of Bruce Lee, the brand-new narrative design and commercial success of Jacky Chen's Police Story (1985) paved the way of applying the cultural logic of action film to mass-produce commercially valuable crime films, and, at the same time, re-forming the concepts of masculinity.

As a greatly successful follower of the narration of Police Story about a Hong Kong police officer who fights for clearing his good name, A Better Tomorrow built a duplicable mode of criminal aesthetics upon the necessity of being violent. It created or deepened the use of certain significant archetypes, such as police-gangster confront interwoven with brotherhood, difficulty for a gangster to go straight, triad heroism and gunfight with kung-fu-like actions, that provided a solid ground to re-activate action films with a new production formula. Concerning the interpretation of masculinity, Sek Kei, a famous Hong Kong film critic, commented that this film had "effectively modernized the male role in martial arts action films in the past." (Karen Fang, 2004: p.39). The modernization he stated is more likely pointing to an adaptation of traditional masculinity whose filmic representation was moulded by wuxia genre in the mid-20th century.

Wuxia, similar to chivalric romance, is a genre concerning the adventure of ancient martial heroes. This genre was especially popular in the 1960s and the 1970s in Hong Kong. The ancient images in Wuxia especially deliver an illusion that it reflects the concepts of Chinese tradition.

The imagined masculinity of wuxia, like Zheng Che's (1968) descriptions of good wuxia movies, necessarily contains "the spirit of esteeming martial qualities and knightly aspirations". He illustrates, "Wu is not chaos and rebellion, but a means to suppress chaos and rebellion. If one is not chivalric [xia], one is not a warrior [wu]."In short, the male roles "cannot be wu and not be $x i a^{\prime \prime}$. (Pp.34-35). In A Better Tomorrow, within the brutal gunfire which performs the audacity and powerfulness of main characters that fulfils traditional expectation on men, 
Chinese tradition assigns men to safeguard their home and country (Baojia Weiguo), so they are expected not to be coward and weak.

there are parallel scenes narrating the interpersonal bonding between the protagonist Sung Tse-Ho and his friend Mark Lee, and between Sung and his younger brother(Sung Tse-Kit) who becomes apolice inspector against him in the second half of the film. Focusing on the brotherhood, we can find that this film not only transcends the hackneyed emphasis on corporeal masculinity prevailing in the post-Bruce period, but also occults a revolt against the ideal male images of orthodox Confucianism.

As Kenneth E. Hall (2012) notes, this film "adopted a tone of seriousness, frequently verging on melodrama, and it stressed especially character and family relationships, in contrast to the 'lady cop' films, in which character and friendship revolve totally around work and are kept on a superficial level." (P.69). The internal conflict between the brothers is certainly a significant point to make A Better Tomorrow standout in the extremely competitive market in the mid-1980s Hong Kong. It extends the diversity of masculine expression through connecting main characters to traditional value and personal emotion, rather than merely to weapon-fetishism or fighting skills. In his book concerning historical representation of Chinese masculinity, Song Geng (2004) states, "Confucianism views family as the cell of society and the state an extension of the family, so the establishment of social order begins at home. The patriarchal authority operated through a set of one-sided hierarchical relations within and out of family: that of father to son, husband to wife and ruler to subject." (P.49). Despite not mentioned by Song, brotherhood (the ethic order between the elder and the junior) is regarded by Confucius as one of the four most important relationships subordinate to the ruler-subject one.

In the chapter 13 of Doctrine of the Mean, it states, "There are four aspects to the Dao of the junzi [ideal man]: not one am I able to fulfil! To serve my father with that which I seek from my son - I cannot do it! To serve my ruler with that seek from my subordinates - I cannot do it! To serve my elders with that which I seek from my juniors - I cannot do it! To first practice towards my friends what I seek from them - I cannot do it!" (Refer to The Doctrine of the Mean. Early Chinese Thought, available at: http://www.indiana.edu/ p374/Doctrine_of_the_Mean.pdf). Brotherhood is one of Confucius's emphasized relationships. Promotion of it, together with others, can optimize and stabilize social discipline.

His highlight of the social function of maintaining family coherence, correlating to the patriarchal authority that Confucianism supports, reveals that maintaining brotherhood, in Confucian sense, is more a moral responsibility than an emotional need. However, in $A$ Better Tomorrow, the director John Woo obviously built the tension between Sung Tse-Ho and his younger brother upon their past sincere communication, rather than upon the responsibility of Sung, as the elder brother, to maintain family harmony. This slight modification of the priority between emotion and responsibility fine-tuned male features that are supposed to be at the side of yang - "aggressive and sublime"(Liu, 2014: p.198) and to concern the use of rationality rather than sensibility. In other words, Woo's men can implement a rational decisionthrough vigorous action, but do not give priority to it. They are rather free from Chinese traditional ethic hierarchy which assigns responsibilities to individuals, especially to men, according to their identities or social positions. 
As Lisa Odham Stokes and Michael Hoover (1999) observe, "From A Better Tomorrow (1986) to Hard-Boiled (1992), Woo has tackled ethical questions by pitting his hero against a corrupt world built on the value of a dollar, where 'necessity knows no law.'" (P.38).

After A Better Tomorrow, John Woo directed 6 films before moving to Hollywood: A Better Tomorrow II (1987), Just Heroes (1989), The Killer (1989), Bullet in the Head (1990), Once a Thief (1991) and Hard Boiled (1992).

In John Woo's films, ethical dilemma necessitates the violent performance of male characters. The ethics under his interpretation is secular, rather than orthodox or religious. It is emotion-oriented, individualistic and self-centred. For sure, the main male characters in crime films must break the law and be criminal. They subordinate collective loyalty to a nation, as what Confucianism mostly emphasizes, to personal free will. As a result, the rise and popularity of crime films that John Woo led to modified the filmic representation of Chinese masculinity, which was still nationalistic and less emotional in Bruce Lee's films.

After A Better Tomorrow, some Hong Kong directors used their innovative ways to interpret the relationship between crime and violence. For instance, Wong Kar-wai and Benny Chan applied romanticising expression in As Tears Go By (1988) and A Moment of Romance (1990), respectively, to link up the result of male violence and the destiny of female protagonists. Herman Yau, demonstrates extreme immorality and immortality, with scenes full of bloodshed, in The Eight Immortals Restaurant: The Untold Story (1993), which is allegedly based on a true crime. Andrew Lau uses violence, both visible and invisibly based on power-relation, to illustrate the out-of-law triad discipline and subculture of triad members through the film series of Young and Dangerous (1995-2000).

The Young and Dangerousfilm series directed by Andrew Lau includes Young and Dangerous (1996), Young and Dangerous 2 (1996), Young and Dangerous 3 (1996), Young and Dangerous 4 (1997), Young and Dangerous 5 (1998), Young and Dangerous: The Prequel (1998) and Born to Be King (2000).

In most cases, crimes are assaultive and man-dominated. Despite mixing criminal narration with various motifs, Hong Kong crime films from the late 1980s to the end of the 1990s remain a strong martial or violent sense, performed by nimble and/or powerful male characters.

Entering the 2000s, Infernal Affairs (2002) revived Hong Kong film industry which had declined for several years. As Gina Marchetti (2007, p.2) concludes, it was at the time that:

[C]ompetition from an increasingly aggressive Hollywood distribution system, the infiltration of the triads into the industry in the 1990s, the impact of satellite television, videos, and video piracy, the "brain drain" that had sucked talent from all sectors of the Hong Kong economy including the film industry since the signing of the Joint Declaration in 1984, and the continuing uncertainty of the consequences of the change in sovereignty in 1997 all fed the crisis at the box-office.

In the perspective of Lo Kwai-Cheung (2010), who applied Marxist thoughts to illustrate the dissolvability of Chinese masculinity under international capitalism, post-handover Hong Kong, which rebranded itself as "Asia's World City", was seeking for "defin[ing] and coordinat[ing] its role between the imminent rise of China under the state agency and the drastic vicissitudes brought by global capitalism in the conjunctures of various historical contradictions and newly emerging problems" (p.23). In his view, rebranding also means a desire of being "dismantled and recombined into something as a measure of change and alteration" (ibid.). 
As a crime film, Infernal Affairs marks a new interpretation of crime, which is significantly out of the paradigm of violence. Crime and punishment became a game of intelligence, rather than a game of physical power. This new rule enabled director Andrew Lau and Alan Mak to inscribe a more sophisticated local allegory on the interaction between two male protagonists, in response to drastic changes in Hong Kong. It simultaneously generated a new formula availing mass-production of blockbuster crime films. As a result, instead of repetitive fighting prevailing during the 1980s and the 1990s, those directors following Lau and Mak's emphasis on intelligence tended to adopt more detective and analytic elements and design more complicated storyline. Their shared methodology, to a large extent, reversed the public focus of ideal Hong Kong male images from the side of physical body to the side of spirit. Different from the spiritual qualities that man is encouraged to possess in romantic films, such as caring and promising, those in, what I call, "neo-crime films" are about individual abilities, such as logical and analytical skills. When some crime-film makers, who paid increasing attention to female audience, added romantic qualities to intelligent male characters, intelligence became a much more generally accepted way to perform masculinity. For instance, unlike Johnnie To's The Mission (1999), which is nearly all about men and guns, Infernal Affairs has plots about the love of Chan Wing-Yan, who goes undercover into a triad, with his therapist who helps release his stress from identity disorder. In Derek Tung-Sing Yee's Protégé (2007), a spy helps a married woman, whom he loves, to get rid of heroin addiction. Dante Lam's Beast Stalker (2008) shows the criminal protagonists' care and guilt about his paralysed wife. While this kind of directors collectively added romantic plots to crime narrations, they, in spite of promoting "heterosocial desire" (Song, 2004) which challenges the central position of "heroism, misogyny, and the male bond" traditionally built upon the patriarchal system, revive the masculinity of scholarship that was prevailing in pre-modern China (p.157).

The term "heterosocial desire" is derived from Song Geng's "homosocial desire" which he uses to signify the man-man social desire in the ancient Chinese society. As he illustrates, "Homosociality is a key to the study of pre-modern Chinese masculinity because the malemale relationship played a more important role in the construction of masculinity than the male-female relationship did."

Under the framework of crime film in which the plots are oriented by the destiny of criminal rather than the love relationship, the subordination of love to intelligence generates a new balance between traditional masculinity and contemporary development of expected manhood.

In the view of Song Geng (2004), the fragile scholar in Chinese traditional opera, who acts as male protagonist in romances, embodies "all the desirable masculine qualities in the literary discourse of ideal heterosexual love in traditional China" (p.viii). Male characters who are wise and knows how to love, but weak, was more admired in ancient China, especially in the Yuen, Ming and Qing dynasties (1271-1912), than those who are good at martial arts but reckless and insensitive. In terms of Kam Louise's wen-wu dyad, both cultural attainment and martial valour can represent Chinese masculinity, but cultural attainment was more preferred in the past. In the context of the post-1997 Hong Kong, after the Asian financial crisis, together with accelerated concentration of global capital and techniques, SAR government advocates the practice of knowledge-based economy. Following the rapid increase of various kinds of courses, such as the programmes of foundation diploma, associate degree and high diploma, and the 
following rise of qualification requirements in the job market, Hong Kong people generally regard academic results and qualifications as the key social capital to improve their living standard. As a response, filmmakers, consciously or unconsciously, began to centralize the position of intelligent men and ingenious plots in their stories, echoing with the public pursuit of knowledge. Given that their return to scholarly masculinity is more a by-product of the change of cultural logic under globalization than a result of deliberate reference to past ideology, we can deem such historical correspondence an accident.

While transnational capitalism is unifying the formula of cultural production, can we say masculinity is losing its national specificity? Can Hong Kong crime films be an evidence to claim that the increasing generalization of masculine representation has made man become everything, and hence nothing? In a practical aspect, Song Geng and Derek Hird (2014) ask similar questions in the introduction of their edited volume Men and Masculinities in Contemporary China. They quotes Yi Zhongtian's "fierce criticism of the 'unqualified' men and women in China' to ask, "Do the 'Chinese' have 'masculinity'? How does Chinese masculinity compare with its counterpart in the West?" (Pp.1-2).

As Song Geng and Derek Hird quoted, Yi Zhongtian points out that "If the men in China are all very manly, then why do we hear calls for a 'search for real men' in China? If Chinese women are all very feminine, then why do we hear phrases such as 'where have all the women in China gone'?."

They, on the one hand, point out the "crisis of masculinity" in China caused by the Chinese men's failure in practising masculinity, and, on the other hand, mention that "new possibilities for gender and sexuality in China", due to "globalization and rapid social transformations" in China, "have significantly challenged and changed traditional notions and discourses" (p.2). In their view, masculinity sticks to everyday life for maintaining its validity and can lose its local specificity due to the merging of different cultures.

For those who agree with the locality of masculinity, Arthur Brittan's (2001) definition is more preferred. Concerning the contradictory and ambivalent male images in relation to women, he states that masculinity is "always local and subject to change" (p.52) and it "refers to those aspects of men's behaviour that fluctuate over time" (p.53). Regardless of his worry about that "male identity is a fragile and tentative thing with no secure anchorage in the contemporary world" (p.53), similar to what Song Geng and Derek Hird stated, his indication of masculinity as a geographical and periodical output of male behaviours at least confirms the impossibility of synchronic masculine similarity. In other words, regional diversity and different paces of cultural development (such as production of new cultural elements and assimilation of local culture to external culture) necessarily lead to a certain degree of local gender configuration. Such gender configuration is replicable but not immediately adaptable. Going back to our discussion of Hong Kong crime films, we can observe that rapid development of online communication platforms which is rapidly eroding geographical boundaries has not yet led to any major change of filmic representation of criminal masculinity, as A Better Tomorrow and Infernal Affairs did. Recent criminal works, especially Sunny Luk and Longman Leung's Cold War (2012), remain a strong adoration of intelligent manhood which sticks to the social context of Hong Kong. In Cold War, directors attempt to use internal struggling between senior police officers to entertain the Hong Kong audience 
who are living in a society with increasingly high power hierarchy. Unlike past crime films whose characters are almost grass-root criminals and/or junior police officers, their innovative focus on a group of more capable and wise men especially differentiates Chinese masculinity in Hong Kong style from the masculinities of the rest of the world.

This made-in-Hong-Kong masculinity is hardly rooted in foreign cultures, and is also hardly assimilated by other masculinities if the geographical and cultural settings of Hong Kong do not encounter a total change. On this point, the American situation of martial-arts film and crime film can provide sufficient exemplification. As David Desser (2000) states, "[T]he American martial-arts film owes its origins and the majority of its defining characteristics to Hong Kong martial-arts films. It is quite possibly the most derivative genre in Hollywood's history and amounts to nothing less than a virtual stealing, a cultural co-operation, of another country's popular cinematic culture" (P.81). Its blank imitation of Hong Kong martial-arts films is just a pastiche of actions which fail to deliver cultural significance. Based on this understanding, Jacky Chan and Jet Lee's martial-arts acting in Hollywood films represent either Chinese masculinity or nothing, but not American masculinity. In the same principle, without coordinating adapted/invented masculinity and local culture, crime films, in the globalized context, can show only foreign male features or male features without geographical reference. As an adaptation of Infernal Affairs, Martin Scorsese's The Departed (2006) is a successful example of translating Chinese masculinity into American masculinity. The humorous, casual and talkative elements added to male characters let them appear to be more American than Chinese. With no doubt, Scorsese's reconstruction of the personalities of male characters reveals the cultural differences between East and West, which have not been dissolved by globalization. Local masculinity is still a matter that is hardly replicated through linguistic effort without cultural translation.

\section{CONCLUSION}

In conclusion, Hong Kong crime film inherited the martial side of masculinity from action films and became a popular genre since $A$ Better Tomorrow was well received in the mid-1980s. Many directors diversified the interpretation of crime in the late 1980s and the 1990s, but still remained a focus on the strength, nimbleness and boldness of men. After the decline of Hong Kong film industry for several years, Infernal Affairs's success renewed the representation of manhood. From the 2000s to now, male characters in crime films are preferably intelligent and wisely-romantic, like the fragile scholar in ancient China. While globalization seems to be eliminating the Chineseness of Chinese masculinity, I argue that geographical specificity and different speed of cultural development lead to the impossibility of synchronic masculine similarity. Besides, through a brief discussion of Hollywood's adaptation of Hong Kong films, I argue that local masculinity is not transformable.

Above all, we may need to focus more on Kam Louie's (2015) notice of "hybrid masculinity", caused by "the growing number of films that are co-productions between Hong Kong, China and Hollywood" (p.8).Such transnational cooperation in film production may minimize the locality of masculinity which is still strongly shown in Hong Kong crime films. At the same time, feminist and queer culture may rewrite the formula of crime films, which are still centred by heterosexual male characters. Besides crime films, potential (or currently-existing) redefinitions of Chinese masculinity in other filmic genres and other artistic forms certainly merit further attention as well. 


\section{REFERENCES}

Brittan, A.(2001), "Masculinities and Masculinism", in Whitehead, S.M. and F.J. Barrett (Ed.), The Masculinities Reader, Policy Press, Cambridge, pp.51-55.

Desser, D. (2000), "The Martial Arts Film in the 1990s", in Dixon W.W. (Ed.), Film Genre 2000: New Critical Essays, State University of New York Press, Albany, pp.77-109

Eno, R.(Ed. and trans.), The Doctrine of the Mean. Early Chinese Thought, available at: http:/ / www.indiana.edu/ p374/Doctrine_of_the_Mean.pdf (accessed14 March 2015).

Eno, Robert, ed. and trans., The Doctrine of the Mean. Early Chinese Thought. Accessed March 14, 2015, http://www.indiana.edu/ p374/Doctrine_of_the_Mean.pdf.

Fang, K.(2004), John Woo's A Better Tomorrow: Autobiographical Stories. Hong Kong University Press, Hong Kong.

Hall, K.E. (2012), John Woo: The Films (2nd edition), McFarland \& Company, Jefferson.

Kam L. (2002), Theorising Chinese Masculinity: Society and Gender in China, Cambridge University Press, Cambridge.

Kam, L. (2015), Chinese Masculinities in a Globalizing World, Routledge, New York.

Liu, X. (2014),Signposts of Self-Realization: Evolution, Ethics and Sociality in Modern Chinese Literature and Film. Brill, Leiden.

Lo K.C. (2010), Excess and Masculinity in Asian Cultural Productions, State University of New York Press, New York.

Marchetti, G.(2007), Andrew Lau and Alan Mak's Infernal Affairs - The Trilogy. Hong Kong University Press, Hong Kong.

Mayer, G. (2012), Historical Dictionary of Crime Films, Scarecrow Press, Plymouth.

Song, G. and D. Hird (2014), "Introduction: Chinese Masculinity: Is There Such a Thing?" in Song, G. and D. Hird (Ed.), Men and Masculinities in Contemporary China, Brill, Leiden, pp.1-2.

Song, G.(2004), The Fragile Scholar: Power and Masculinity in Chinese Culture. Hong Kong University Press, Hong Kong.

Stokes, L.O. and M. Hoover (1999), City on Fire: Hong Kong Cinema, Verso, London.

Zhang C. (1968), "Tan wuxia pian" ("A discussion of Wuxia Pictures"), Nanguo dianying ("Southern Screen"), No. 126, pp. 34-35. 


\section{Author Biography}

Gabriel F.Y. Tsang is currently a PhD student and the postgraduate representative of the Department of Comparative Literature at King's College London, and a visiting scholar at the National University of Singapore. He formerly studied at the University of Hong Kong for his MA degree and at the City University of Hong Kong for his BBA degree, during which he got chances to study at Tsinghua University, Nanjing University and the Renmin University of China. He is President of the British Postgraduate Network for Chinese Studies. His recent works include 'Political Narratology and Consensual Development in Post-Mao China' published in the Journal of Narrative Theory and 'Beyond 2015: Nihilism and Existentialist Rhetoric in Neon Genesis Evangelion' published by the Journal of International and Advanced Japanese Studies. 